\title{
4
}

\section{Scholar, Spy, Passionate Realist}

\section{Geoffrey Barker}

Paul Dibb understands the international concern over Islamist terrorism, but he retains a clear historical and strategic perspective on it: 'It's just plain nonsense to compare terrorism with the dangers of global nuclear war between the USSR and the US in the 1970s and 1980s, which would have wiped out 180 million people in the first 24 hours,' he says: 'That was not some theoretical threat, as those of us who had to live with it knew only too well. It was a very real global threat to the existence of the human race.'

Dibb is well qualified to rate and to compare the gravity of threats to Australia and the world. Throughout his distinguished career in Australia's defence, academic and intelligence establishments, he has been privy to the deepest anxieties of Western powers and to their darkest secrets in the Cold War years. Intellectually he is a balanceof-power realist whose approach to security issues essentially matches those of Hans Morgenthau, George Kennan and Henry Kissinger. He has engaged directly and personally with Australia's Soviet and Chinese communist adversaries and with Australia's Asian neighbours, friendly and hostile; he has studied the pathologies lurking in the international system, advising governments and teaching students how to understand and manage the threats to global peace and security. 
Dibb is perhaps best known as the author of the 1986 Review of Australia's Defence Capabilities (Dibb Review), which fundamentally recast national defence policy by refocusing defence finance and force structure on the defence of Australia and on defence self-reliance. In the same year he published his groundbreaking study The Soviet Union: The Incomplete Superpower, ${ }^{1}$ one of the first books to argue that the apparently awesome Soviet Union faced internal problems that could lead to instability and deepening crisis, although he also argued (perhaps too cautiously) that 'the Soviet system is not likely to collapse'. Formidably energetic and hardworking, Dibb still produces characteristically acerbic academic papers and newspaper articles. He continues to give lectures and seminars, to make media appearances, and to represent Australia at international forms including the Association of Southeast Asian Nations (ASEAN) regional forum (ARF) Experts and Eminent Persons (EEP) group.

His work with the Australian Security Intelligence Organisation (ASIO) in the dangerous world of Cold War counterespionage is less well-known. So is his personal and professional relationship with the late Don Marshall, ASIO's charismatic counterespionage chief. Some of that story can be told now. Born in 1939, Dibb was just 25 when he was introduced to the shadowy world of counterespionage. It was 1964 and, had he seen the future, he would have been astonished to see himself closely involved in counterespionage activities until the eve of the collapse of the Soviet Union in 1991.

In the mid-1960s, Dibb was a junior officer in the Bureau of Agricultural Economics (BAE) in Canberra researching prospects for wheat sales to the Soviet Union. A new recruit to the Australian public service from the United Kingdom, Dibb held a degree economics and geography, including Russian studies, from Nottingham University, spoke Russian, and admired Russian culture (especially music) as much as he abhorred Soviet communism. Australia was a place of infinite possibilities for a bright lad from the Yorkshire market town of Pontefract, which had been besieged three times by the Parliamentarians during the English civil war in the 17th century. The son of a coalminer, he had been rejected by the British foreign office because of his humble class origins and his Yorkshire accent, and because he had not been

1 Paul Dibb, The Soviet Union: The Incomplete Superpower (London: International Institute for Strategic Studies and Macmillan, 1986). 
to Oxford or Cambridge universities. England's loss was Australia's gain when he arrived in Sydney in 1964 before heading for his job in Canberra.

His espionage career started innocently enough with an authorised visit to the Soviet Embassy to collect Soviet trade statistics publications for his research. Soon afterwards a supervisor told him that ASIO wanted to talk to him. Dibb guessed ASIO had observed his embassy visit and assumed the spy agency wanted his estimate of the Soviet wheat crop for the year. (This work brought Dibb to the notice of trade minister John 'Black Jack' McEwen: his correct estimate that Australia would be able to sell wheat to the Soviets, providing a major windfall for wheat farmers, pleased Black Jack very much indeed.)

But ASIO was not interested in Soviet wheat production figures. It wanted Dibb to do something infinitely more sensitive and potentially dangerous - to cultivate Moscow's diplomats in Australia with the view to obtaining information and, ultimately, persuading one of them to defect. The approach was made to him at a pub in north Canberra by the rising star in ASIO counterespionage, who was known throughout the organisation as DRM: Donald Ralph Marshall.

Marshall was a gregarious man of White Russian background born in China. He spoke with a serious stammer, which he told Dibb resulted from having seen a Japanese soldier bash out the brains of his baby sister against a brick wall in a Japanese internment camp. Marshall enjoyed the company of hard-drinking men and attractive women and had an hilarious, at times scatological, sense of humour.

Dibb says he might not have been persuaded to work with ASIO if anyone other than Marshall approached him: 'I couldn't resist the call of something that was so important to Australia and which also offered excitement and potential danger. It was dead-sexy stuff to be doing. And Don, although born a Russian, somehow exemplified the quintessential Australian larrikin. He had incredible strength of personality. If it had been anyone less charismatic I may have had second thoughts.'

Marshall was a man fated to work in Soviet counterespionage. His father Bill (Vladimir) fled from the Soviet Union to Australia in the 1920s, served in the Australian army and returned to Shanghai to serve in the police force. Don, the same age as Dibb, was born in 
Shanghai in 1939 (his original name was Donal Mischenko) and he spent his childhood in the internment camp with his mother after the Japanese invasion. After the war, the family was reunited and Bill worked with the Hong Kong police before moving to Australia and joining ASIO, where he played a key role in the 1954 defection of the Soviet diplomats Vladimir Petrov and his wife Evdokia. Don attended the famous Fort Street High School in Sydney and studied philosophy at The Australian National University (ANU) before following his father into ASIO.

Dibb got to know Marshall slowly over a close 34-year friendship that endured until Marshall's death in 1999. Marshall's offer led Dibb into what has been called 'the wilderness of mirrors', the covert world of counterespionage where things are not always as they seem, where truth and trust are relative and where human weakness, greed and credulity are exploited in the service of national security. Ultimately, their relationship resulted in Dibb supporting ASIO's counterespionage efforts until the collapse of the Soviet Union in 1991.

Marshall told Dibb that ASIO wanted him to cultivate senior Soviet diplomats to get information on Soviet global strategy and its defence and intelligence targets in Australia, and to encourage defections. Although the Petrov defections had occurred 10 years earlier, Australia, as a US ally, remained a major target of Soviet espionage as Moscow sought to penetrate US secrets via Australia, including Australia's access to classified US satellite intelligence and electronic signals intercepts.

Soon after their first meeting, Marshall took Dibb to meet ASIO's legendary Deputy Ron Richards, who was a central figure in the Petrov affair and was the only man Dibb ever heard Marshall address as 'Sir'. Richards was direct: 'Will you work for us?' he asked Dibb. Dibb had only one condition, he recalls: 'I said I wanted my career protected.'

Marshall's influence on Dibb was deep and lasting: 'In my early years in Australia he taught me about Australian nationalism and Australian national interests. He taught me that what we were doing against the Soviet Union was of the utmost importance and that we were not to talk about it - not even to those in Australian intelligence or the US embassy who he did not trust. And he taught me that we did not always tell the Americans and the British everything - especially when 
they were being threatening in their demands. Don was a dynamic extrovert personality and he believed profoundly in the goodness of what we were doing despite the cynical views of others', Dibb says.

Dibb's disclosures of his ASIO activities throws new light on Australia's role in the Cold War - a role mostly remembered for the Petrov defections, the expulsion of the Soviet diplomat Ivan Skripov in 1963, the 1983 Combe-Ivanov affair, ${ }^{2}$ and for the part played by the Pine Gap, Nurrungar and North West Cape bases in global US nuclear warning and targeting systems. Dibb had top-secret security clearances for these installations for more than 25 years and the first public hint of his ASIO involvement appeared in a collection of essays commemorating the 40th anniversary of The Australian National University's Strategic and Defence Studies Centre (SDSC), which Dibb headed from 1991 to 2003.

Des Ball revealed in that book that Dibb was tasked by Marshall to get the views of the Russians 'on issues concerning the central strategic balance and to discern the real interests and priorities, and perhaps persuade one or other of them to defect'. ${ }^{3}$ Dibb did not succeed in 'turning' a Soviet diplomat. 'They were either too smart or they had a mole deep inside ASIO', he says.

A still highly secret hunt was mounted for a suspected ASIO mole, but none was found. Nevertheless, the Americans had their suspicions and, in 1981, the CIA Station Chief in Australia, Michael Sednaoui, told Dibb that his specific mission was to find out if there was a mole in ASIO. Sednaoui's posting was cut short by ill health (which he said he feared the Russians had caused) and he reached no conclusions, but he told Dibb he had some 'serious concerns' before he left Australia.

Soon after starting his secret ASIO work, Dibb left the BAE and took a research posting at ANU where he wrote a book on Siberia. He joined the Defence Department in 1970. From 1974-78 he headed the National Assessments Staff (NAS), which drafted national intelligence assessments for the National Intelligence Committee (NIC) and he was

2 See Shane Maloney \& Chris Grosz, 'David Combe \& Valery Ivanov', The Monthly, Aug. 2006, www.themonthly.com.au/encounters-shane-maloney-david-combe-valery-ivanov--274.

3 Desmond Ball, 'Reflections on the SDSC's Middle Decades', in Meredith Thatcher \& Desmond Ball (eds), A National Asset: Essays Commemorating the 40th Anniversary of the Strategic and Defence Studies Centre, Canberra Paper No. 165 (Canberra: Strategic and Defence Studies Centre, 2006), p. 77. 
the government's leading Soviet intelligence expert. From 1986-88 he was Director of the Joint Intelligence Organisation (JIO, now the Defence Intelligence Organisation (DIO)) and from 1988-91 he was Deputy Secretary (Strategy and Intelligence) in Defence.

Few would dispute that Dibb's most important public and personal contribution to defence policy was the Dibb Review. He was commissioned to produce the report by the then Defence Minister Kim Beazley, himself a formidable defence intellectual, when he was an external consultant to the government. The Dibb Review remains a seminal document in Australian defence policy: it put paid to the era of 'forward defence', which had been discredited by the Vietnam War. Instead it proposed a layered national defence of Australia to deny potential aggressors the possibility of successfully attacking the continent through its sea-air approaches to the north and north-west of the continent. It also proposed the policy of defence self-reliance at the heart of the 1987 and subsequent Defence white papers.

The Dibb Review was a controversial and contested document, widely praised and widely criticised. Dibb's views are still contested by those who support the creation of heavily armoured Australian expeditionary defence forces capable of deploying to distant theatres and aggressively supporting the United States in contingency planning for global war. The Dibb Review declared the joint US-Australia intelligence facilities at North West Cape, Pine Gap and Nurrungar, plus staging rights for US ships and aircraft, 'a sufficient tangible contribution to the [ANZUS] alliance'. Dibb at heart is a geographer and he takes pleasure in mocking the argument that geography and geographical proximity no longer matter in strategic policy. 'If that is true,' he asks, 'why are we more concerned with Papua New Guinea than we are with GuineaBissau?' He has yet to be answered.

The point is that the Dibb Review brought the key focus of defence policy home to the security of Australia and its regional neighbours. It is the strategic framework within which Australian Defence white papers are still shaped and the defence force structure is (imperfectly) decided. It is challenged primarily by contrarians, ideologues, and gung-ho military officers who oppose its essentially defensive attitude and note that Australia's major troop deployments still tend to be to distant theatres (which, of course, ignores the demonstrated flexibility of Dibb's defence of Australia doctrine). 
As a frontline practitioner in security, it is perhaps inevitable that Dibb's approach is deeply realist: for him, national interest and raison d'état trump the moralistic and legalistic postures of the liberal internationalists. Dibb sees the international order of sovereign states as inherently anarchic and he believes the anarchy is best managed by balancing power through interlocking networks of treaties and alliances to ensure that no one aggressive power dare try to overwhelm others. Dibb accepts the reality of violence in international relations and the need for adequately funded and equipped armed forces. (His concerns over government inconsistency in the management of defence funding and policy, as well as the defence force structure and industrial support, have been major themes of his widely reported public statements.) For Australia, his support for regionally focused defence self-reliance acknowledges the overarching importance of the US alliance as the ultimate last-resort guarantor of Australian security. He admires American intellectual and technical innovation and he has powerful friends in Washington.

Yet Dibb is no reflexive hawk on social policy issues. The Yorkshire coalminer's son remains sensitive to the hardships and dangers endured by the blackened men he saw emerging from the pits and mills to live in meagre poverty in grim, terraced cottages without adequate hygiene or medical care (at least until Britain's postwar national health service was established). He remembers, as a child, hearing the thump of German bombs landing on Kingston upon Hull. He was aware of the sometimes violent industrial struggles between miners and mine owners, and he regrets the social and economic impact on parts of Yorkshire of mine closures from the 1970s. Even today, Dibb slips easily and amusingly into Yorkshire dialect to recite some long-remembered Yorkshire proverb, poem or prayer. His concern for the hard-pressed men and women of the Pontefract region may have been one of the deeper motivations driving his work in international security. His connoisseur's taste for high-performance sports cars may signal his determination to show that he has come a long way from the austerity of postwar Pontefract.

Dibb became the head of SDSC in 1991, a post he held until 2003. He remains Professor Emeritus, deeply engaged in the work of the centre and the national strategic policy debate. Dibb has always been part scholar/teacher/academic analyst and part advocate/activist/ adviser. He does not shy away from the role of provocateur if he believes 
provocation is necessary to focus public and political attention. In his academic, defence and ASIO careers he has spent his life observing, analysing and, at times, engaging with the most intractable strategic policy issues in his life-long mission to reduce the threat of nuclear Armageddon.

The 1986 publication of The Soviet Union: The Incomplete Superpower caused controversy and some grief for Dibb in both the United States and Australia. Some in the CIA and in the Australian intelligence community thought it too soft on the Soviet Union. Dibb remembers that Robert Gates, former US Secretary of Defense, but then Deputy Director of the CIA and the agency's leading Soviet expert, did not recognise even in the mid-1980s that the Soviet Union had serious weaknesses. Neither did Australia's Office of National Assessments (ONA), the federal government's main intelligence analysis body. They were, in Dibb's view, unable to see the weaknesses because of an apparently deep psychological need to portray the Soviet Union as an expansionist and aggressive nuclear-armed power confident in its ability to fight and win against weak and beleaguered Western powers.

The Australian analysis of the Soviet threat at the time was greatly influenced by contacts between Australian intelligence analysts and their US counterparts. Its flavour is captured in the 1983 Strategic Basis of Australian Defence Policy prepared for Federal Cabinet by the top-level Defence Committee, chaired at the time by Bill Pritchett, the Defence Secretary, and with Michael Cook, then Director-General of the ONA, as an 'invited consultant'. The once-secret Australian Eyes Only document claims in part:

The US sees the USSR as able to destroy virtually all US missiles on the ground using only a portion of Soviet forces, while the US cannot inflict similar damage on Soviet forces even using its entire ICBM force ... US strategic planners must calculate that in a full nuclear exchange the USSR could have the final advantage in terms of survival at some level short of national extinction.

Dibb recognised the Soviet threat and argued that Soviet military power was 'great and constantly expanding'. He agreed with the Defence Committee report that nuclear conflict was 'improbable', but he disagreed profoundly with the overall thrust of committee report. He wrote of 'a narrow and distorted Western focus on implausible contingencies' that had led to 'an exaggeration of Soviet military 
strength'. In what amounted to a contemptuous dismissal of the report, Dibb added: 'It is the West that is proclaiming Soviet military superiority, not the USSR, but belief in our words could help to produce the timidity and lack of confidence that we are seeking to avoid.'

Dibb took a broad view of Soviet economic, social and technological progress and concluded that it was a global power 'only in the military dimension'. The country, he said, had a semi-developed economy with a poor standard of living, backward technology and a grossly inefficient system of central planning. He said it was facing serious challenges 'perhaps leading to instability and deepening crisis'. He did not predict the collapse of the Soviet Union, but the Berlin Wall came down only three years after publication of his book, heralding the collapse of the Soviet Union and its empire. Dibb's assessment of the Soviet threat had proved to be much more insightful and accurate than the Defence Committee's alarmist analysis.

The book also landed Dibb in a brutal bureaucratic conflict with Defence's internal Office of Special Clearances and Records, known as OSCAR. He had returned to Defence to be told by an aide that OSCAR, set up to oversee personnel security clearances, had decided without authority to take on a counterespionage role and was illegally tapping the telephones of some military officers. Outraged, Dibb reported the issue to the then department Secretary Tony Ayres who ordered him to task Don Marshall to shut down OSCAR and to quietly sack its staff. Marshall did so with ruthless and surgical bureaucratic skill, and OSCAR and its illegal activities vanished into the now only faintly remembered mists of internal defence politics.

Throughout the Cold War, Dibb remained closely involved with Marshall and with ASIO's efforts to cultivate and turn Soviet diplomats in Canberra. 'I enjoyed the cut and thrust', he recalls. 'You always remember the first person you try to cultivate.' Dibb's first person was Nikolai Poseliagin, the Third Secretary in the Russian embassy, who was to return to Australia as First Secretary in 1974 when Dibb headed the NAS. 'I had two goes at him', he recalls. 
Dibb also sought to cultivate the Deputy Chief of Mission Yuri Pavlov and Minister-Counsellor Igor Saprykin. Dibb describes them as two of the most impressive Soviet representatives to serve in Australia. 'We knew the Soviets were sending very competent people here. Saprykin and Pavlov were sophisticated people', he says.

Marshall suggested that Dibb invite Saprykin home for dinner. 'We'll have the place wired for sound. Get the bastard drunk', he told Dibb. Dibb carried out Marshall's suggestion and after a heavy meal and many, many drinks, Saprykin unexpectedly remarked that he was aware of what was the big issue in Australian society in that summer of hard-fought Ashes cricket dominated by two lethal Australian fast bowlers. 'Paul,' he said, quoting a popular ditty, 'ashes to ashes, dust to dust, if Lillee don't get you, Thomson must.' 'Looking back,' Dibb recalls, 'I think that was when I realised he was a bit too smart for us.'

In 1968, one month after the Soviet invasion of Czechoslovakia, Dibb made his first visit to the Soviet Union. Marshall warned him that Britain's MI6 would ask him to do 'silly things'. Dibb, without elaborating, says he was approached 'in a rather cack-handed way, and I politely refused'. On his second trip to the Soviet Union in 1976 the then Secretary of Defence Sir Arthur Tange told him: 'I want an Australian view, not an American or British view. Stay with Jim Plimsoll (the Australian ambassador) and watch yourself.' In Moscow Dibb was not even allowed into the embassy courtyard without an Australian minder to protect him from Soviet provocations.

The top-secret report he delivered from Moscow in 1976 as head of the NAS created a stir in Australian intelligence circles. In talks with top-level officials of the Soviet Institute for the US and Canada Studies, Dibb established, among other things, that the Soviet Union had nuclear targeting priorities that included Australia. He also established the extent of a military base set up by the Soviets at Berbera on the coast of north-west Somalia to match the expanding US base at Diego Garcia in the Indian Ocean. Dibb's report, previously secret, said the Soviet officials had told him the USSR saw a potential threat from US missile-firing submarines in the Indian Ocean. They warned that if such an attack were directed from North West Cape [the communications station on the Western Australian coast] it could involve Australia in Soviet response considerations'. The officials also told Dibb that the USSR had installed a missile-handling facility, a 
communications station, an airfield, barracks, limited repair facilities and fuel tanks at Berbera. The Russian message was a frank warning to Australian defence planners that the US-Australia joint intelligence collection and communications facilities at North West Cape, Pine Gap and Nurrungar were potential nuclear targets. It also signalled the Soviet ambition to match the Diego Garcia installation.

Dibb's trips to the Soviet Union were obviously perilous given his secret counterespionage work in Australia. If the Soviets had learned that he was involved in cultivating and trying to 'turn' Russian diplomats, he might have spent a long time in a very cold part of the vast Russian tundra. As it was, he managed to supply an original Australian view of Russian policy in cables to defence planners in Canberra. Dibb also travelled regularly to the United States where he consulted with what he calls the covert side of the CIA. On one visit he met James Jesus Angleton, the CIA's legendary Soviet counterespionage chief. He recalls Angleton telling him that the Sino-Soviet split was a KGB set-up to fool the West.

Dibb's covert work with Marshall continued in Canberra, but their relationship was not just cloak-and-dagger business. They would drink together in the now-demolished Deakin Inn where Marshall enjoyed the company of the attractive young women who came into the bar. When they asked where he worked he would stutter: 'I ... I ... I'm a V ... V ... Victa 1 ... lawnmower salesman.'

Marshall rose through ASIO's ranks to become Director of the Canberra regional office running counterespionage, and an Assistant DirectorGeneral. He spent his last working years as Director of Defence Security - a post that Tony Ayres directed Dibb to secure for him. The end of his life, after two failed marriages, was tragic.

'When the Soviet Union disappeared, Don's raison d'état disappeared', Dibb recalls. 'His world fell apart for personal reasons and he drank heavily.' Shortly before moving to Defence, Marshall was invited to visit ASIO's new Russell Hill offices. 'What are you doing here, Don?' a friend asked him. 'W ... W ... What are any of us doing here?' he replied gloomily. 'I will never forget telephoning him at home late in 1998 after Ron McLeod, the Inspector-General of Intelligence, rang me to say that Don's personal life was a real mess. I invited him for 
GEOGRAPHY, POWER, STRATEGY AND DEFENCE POLICY

lunch with a group of old ASIS (Australian Secret Intelligence Service) friends. "N ... no mate. I ... I can't do it", Marshall replied, and hung up his telephone. A few weeks later he died.'

'I think he was determined never to see his 60th birthday,' Dibb says. 
This text is taken from Geography, Power, Strategy and Defence Policy: Essays in Honour of Paul Dibb, edited by Desmond Ball and Sheryn Lee, published 2016 by ANU Press, The Australian National University,

Canberra, Australia. 